\title{
The Military Industrial Complex In a Developing Country: Lessons from the Republic of Turkey
}

\author{
Tresno Wicaksono \\ President Center for International Studies (PRECIS), President University, Bekasi, Indonesia \\ tresnowicaksono@gmail.com
}

\section{Anak Agung Banyu Perwita}

School of International Relations, President University, Bekasi, Indonesia

aabanyu.perwita@gmail.com

Submitted: 24 September 2019; Revised: 04 April 2020; Accepted: 22 July 2020

\begin{abstract}
Abstrak
Turki merupakan contoh negara berkembang yang memperhatikan perkembangan industri pertahanannya. Sejak awal menjadi republik pada tahun 1923, banyak perusahaan industri pertahanan yang didirikan, baik milik negara maupun swasta. Belakangan ini, perkembangan industri pertahanan Turki telah menunjukkan kemajuan yang signifikan dengan kemampuan membangun produk pertahanan dalam negeri seperti tank dan kapal dengan muatan lokal yang besar. Tujuan industri pertahanan Turki di bawah pemerintahan Erdogan saat ini adalah membangun kemandirian industri pertahanan 'penuh' pada tahun 2023, tepatnya seratus tahun dari usia republiknya. Untuk mencapai tujuan tersebut, Turki telah menetapkan 'struktur industri pertahanan' yang mirip dengan konsep 'Kompleks Industri Militer' Eisenhower. Sinergi pemangku kepentingan diantara Kompleks Industri Militer Turki telah membuat Turki secara progresif memenuhi tujuan Erdogan untuk kemerdekaan militer secara 'penuh' melalui pelaksanaan dan keberhasilan proyek pertahanan nasionalnya. Oleh karena itu, dengan menggunakan metode penelitian eksplanatori, penulis menjelaskan keberadaan Kompleks Industri Militer Turki dari peran dan sinerginya masing-masing yang membawa dampak signifikan bagi negara. Artikel ini berargumen bahwa perkembangan industri militer di Turki dalam kurun waktu 2011 hingga 2017 dapat memberikan pengalaman dan pelajaran berharga bagi negara berkembang lainnya untuk memperkuat level industri pertahanan nasionalnya. Kata Kunci: kompleks industri-militer, negara berkembang, kemandirian industri pertahanan, industri pemerintah, hubungan akademik
\end{abstract}

\begin{abstract}
Turkey is an example of a developing country concerns with the development of its defense industry. Since the early of its republican in 1923 , there are many defense indus $\neg$ try companies established, owned by both state and private sectors. Lately, Turkish defense industry development has shown significant progress by the capability to build its indigenous defense products such as tanks and ships with most local content. The current objective of the Turkish defense industry under Erdogan administrative is to establish a 'full' defense industry independency by 2023, precisely a hundred years of its republic age. To achieve the objective, Turkey has established its 'defense industry structure' similar to Eisenhower's concept of 'Military-Industrial Complex'. The synergy of stakeholders among the Turkish Military-Industrial Complex has led Turkey to progressively fulfill Erdogan's objective of a 'full' military independency through the execution and success of its national defense projects. Therefore, by using the explanatory research method, the authors explain the existence of the Turkish Military-Industrial Complex from each role and synergy, bringing significant impacts to the state. This article argues that the development of the military industry in Turkey, covering a timeframe of 2011 to 2017, could provide valuable experiences and lessons for other developing countries to strengthen their national defense industry level.
\end{abstract}

Keywords: military-industrial complex, developing country, defense industry independency, government-industry, academic relations

\section{INTRODUCTION}

Turkey's initiative to develop its defense industry was started in 1975 when the US imposed arms embargo during the 1974 Cyprus War. This situation became a wake-up call for Turkey to decrease its dependency on imports of major military items and build an independent defense industry (Global Security, 2018). Shortly in 1985, the Turkish Parliament issued a national policy; the 1985 Constitution, Law No. 3238 (SSB, 2017) 
referring to "the establishment of an institution capable of generating long term defense policies and principles and supplementing them with a continuous flow of financial resources" (Ongur \& Partners International Law Firm, n.d.). Through this law, the Undersecretariat for Defense Industries (SSM) became the primary institution to fulfil the function by its principle to meet military requirements (Ongur \& Partners International Law Firm, n.d). Since its establishment, the SSM has emerged into a large defense institution by the number of firms and individuals involved.

Straight forward to 2006, the SSM had impacted Turkey's economic income through the defense sector growth, aerospace exports, and research and development (SSB, 2017). The political and military sectors of the state were also signified with the growth of Turkish defense industry capability. As a remarkable moment of its defense industry development, in 2008, Turkey launched its very first MILGEM class corvette, 'TCG Heybeliada' starting its services for the Turkish Navy in 2011 (Naval Technology, n.d.). Moreover, the Turkish defense industry was also able to develop its indigenous helicopter, tank, unmanned aerial vehicle, and training aircraft for the Turkish armed forces (Demir, Caymaz, \& Erenel, 2016).

Furthermore, Demir, Caymaz, and Erenel, identified the existence of four stakeholders under the Turkish defense industry consisting of government, industry, military, and research. The existence of these stakeholders then defined into the Turkish Military-Industrial Complex by the authors in this research. The synergy among the stakeholders expedites the progress of the Turkish defense industry's independency through the success of national defense projects. Therefore, this research provides further elaboration on the role of each stakeholder, including the synergy built among them to picture how they signify one another in carrying out the national defense projects.

Erdogan's ambition of having defense industry independency in this context still becomes the central policy of the Turkish government. In line with this, one of the defense analyst and columnist of the Hurriyet newspaper, Burak Bekdil, argues that Turkey's rulers firmly believe that Turkey cannot be the regional power they wish it to become without a deterrent military force (Sezer, 2015). In 2015, during an event of 100thAnniversary of the Battle of Gallipoli, President Erdogan stated that:

"So As long as there are assailants in the world, we will always be required to be ready for defense,...our goal is to completely rid our defense industry of foreign dependency by $2023, .$. by 2023 , a locally-made combat plane will fly the Turkish skies." (Sezer, 2015).

\section{RESEARCH METHOD}

In this research, the authors utilized the explanatory research method. According to Lisa, the explanatory research is intended to explain, rather than to describe the phenomena studied (Given, 2008). Furthermore, the explanatory research also plays - "an instrumental role in terms of identifying reasons behind a wide range of processes, as well as, assessing the impacts of changes on existing norms, processes"- (Zikmund, 2012). The data for this research were obtained from both primary and secondary resources provided online. To be more specific, this research relied heavily on the data and official statements from the Turkish government, military, research institutions, and related individuals. The research was then complemented by the data from trustworthy think tanks, newspapers, and military databases to provide a comprehensive and clear elaboration.

\section{RESULT AND DISCUSSION THE EXISTENCE AND ROLE OF TURKISH MILITARY-INDUSTRIAL COMPLEX}

In 2016, Kadir Alpaslan Demir, Ebru Caymaz, and Fahri Erenel introduced the existence of stakeholders in the Turkish defense industry through their publication, which then adopted in this article as the Turkish Military-Industrial Complex. According to them, clustering has many benefits in developing defense systems by bringing all the stakeholders together.

"The success of firms in the cluster is higher than the firms outside the cluster due to the fact that no firm can overcome all the challenges related to the 
development of defense system while the firms in the cluster should form effective collaboration circles both within the cluster and outside the cluster." (Demir, Caymaz, \& Erenel, 2016).

The framework in figure 1 showed that government, industry, military, and research institutions aim to develop Turkish defense industry independency. Government as the decision-maker here needs industry to execute the defense projects, while the project initiation itself mostly comes from the necessity of the military sector. Furthermore, most of the technology advancement in Turkish defense industry is the result of research institutions.

\section{The Role of Government in the Military-Industrial Complex}

The role of the Turkish government has been very significant since the beginning of its independency, especially in the 1980s following the establishment of the Undersecretariat for Defense Industries, SSM. Straight forward to the 2011-2017 period, the government's role was supporting and ensuring the sustainability of the Turkish defense industry by publishing strategic policies through the SSM. The government was responsible for managing the area of industry participation through technology advancements, technology transfer, and foreign cooperation while also responsible for

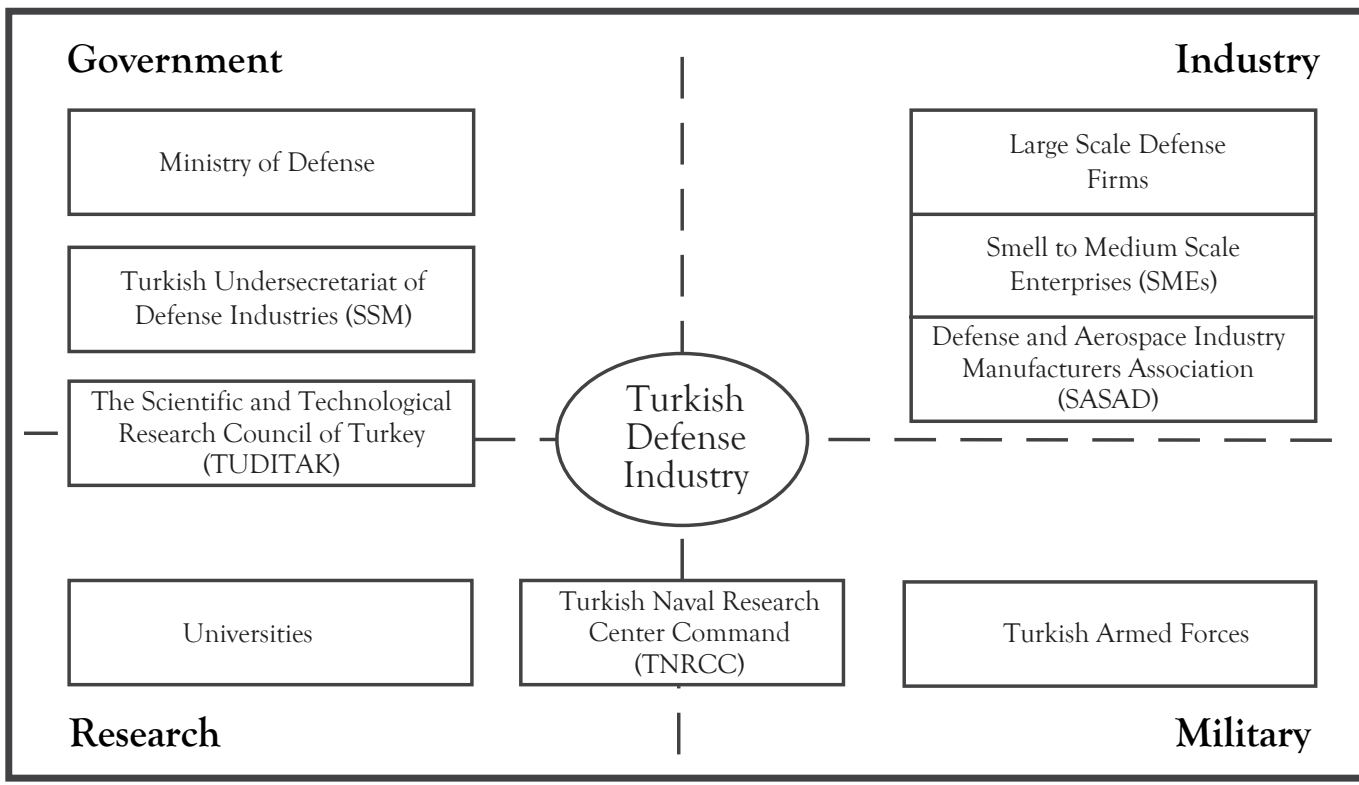

Figure 1. Turkish Military-Industrial Complex (Demir, Caymaz, \& Erenel, 2016)

managing the area of industry participation through technology advancements, technology transfer, and foreign cooperation while also responsible for maintaining political and economic stability by creating constitutional policies. Hence, Turkey's government agency assigned to handle these responsibilities is the Ministry of National Defense dealing with two legal units and the dual role of the government - the TUBITAK research agency.

\section{Ministry of National Defense}

The Ministry of National Defense of Turkey becomes the highest government agency to deal with national security as it supervises the Undersecretariat for Defense Industries (SSM) and works with the Defense Industry Executive Committee (SSIK). Since the very beginning, the SSM has given an independency to manage the development and modernization of the Turkish defense industry through major systems procurement, industry policymaking, localization, and research and development (Aktas, 2016). It has three strategic 
priorities, where the main one is to ensure the sustainability of the defense industry. To fulfils its main strategic priority, the SSM has produced 'SSM Industrialization Policy' (Aktaş, 2016) concerning (1) incentivize involvement of SMEs in the defense business; (2) export promotion of Turkish defense products; (3) multiple incentives for SMEs; (4) cluster formation; (5) involvement of universities and institutions, and; (6) strengthening technological capabilities of Turkish industry.

Furthermore, there is a legal unit called SSIK chaired by the Prime Minister, with the Committees comprising the Turkish Armed Force (TAF) Commander, the Minister of Interior, and the Minister of National Defense. This unit instructs SSM for "research and development of modern weapons and equipment to be supplied together with producing prototypes, providing advance loans, and determining long term orders and other financial and economic incentives." It also undertakes decisions on defense industry product exports, offset, and bilateral trade as well as coordinates the defense industry and related organizations. Hence, two units working together with the Ministry of National Defense have a significant role as the top-level decision-makers and executors dealing directly with the project.

\section{TUBITAK}

TUBITAK is an example of a stakeholder situated in a double role; the role of government and the role of research. According to its official website, TUBITAK is an organization with administrative and financial autonomy to organize, coordinate, and encourage research and technological development goals (Tübitak, 2018). The role of TUBITAK is essential for the Turkish defense industry as it covers MAM, BILGEM, technology transfer, $R \& D$ units, $R \& D$ support units, and projects/products and services (Tübitak, 2018).

Specifically, within the research and development unit, TUBITAK has the TUBITAK SAGE having the role "to perform research and development activities for defense systems including engineering and prototype production, starting with their fundamental research and conceptual design" (SAGE Tübitak, n.d.). Some notable results of products/projects are the stand of the missile, precision guidance kit, penetrator bomb, wing assisted guidance kit, thermal battery, and Toros 230A/260A (SAGE Tübitak, 2013). In short, this agency works on the very substantial defense research and development projects requiring direct supervision from the government.

\section{The Role of Research in the Military-Industrial Complex}

According to Ziya Altunyaldız, "the production and research and development (R \& D) are the two elements that stand out and that have played an important role in the development of the defense industry" (Daily Sabah, 2018). It resonates to the statement of Merve Seren believing that one of the factors in the local content growth of the Turkish defense procurement from $24 \%$ in 2002 to $68.5 \%$ in 2016 was due to the research and development activities conducted, with the remaining $40 \%$ included in the ongoing research and development of sophisticated technology products (Seren, n.d.). However, there is still criticism of the quality of human resources from Mevlutoglu, namely the lack of focus and vertical expertise in the industry itself.

\section{Universities}

Along with the criticism, in 2012 the SSM conducted a Program to Develop Researchers for Defense Industry or Savunma Sanayii Araştırmacı Yetistirme Programi (SAYP) aiming to educate the students who will receive a postgraduate education as a qualified $R \& D$ member in the field of defense by the means provided by the defense industry companies (SSB, 2017). By 2018 there were 31 universities and 35 defense industry companies included in the scope of SAYP, such as Koc University, Ankara University, Bilkent University, and Kirikkale University, which have been working closely to the industry. For the application basics of this program, there are four possibilities (SSB, 2017):

- Fresh graduate within the scope of SAYP will be accepted in the cooperation of the defense industry organizations;

- Researchers continue their education in 
universities while working on the project;

- Researchers become a part-timer for the university, and the relevant industry; and

- The graduate research article topics which are determined by the authorities of the university faculty and related industry institutions directed by RCC, managed and approved by RCC.

The increasing number of local contents of Turkish defense industry procurement is significant as it leads to its defense industry's independency in the future. This growth reflects the vital role of research and development stakeholders that Turkey has been working on. Looking back to figure 1 of the Turkish Military-Industrial Complex, involving university as a research stakeholder might become a wise decision the SSM has taken. This decision benefits both the state and university students for together developing the state's defense industry.

\section{The Role of Military in the Military-Industrial Complex}

In the framework of the Turkish Military-Industrial Complex, the military's role is crucial. According to Rafat Wisniewski, the military is the basis of the entire defense industries and still becoming the main driving force behind the state's support to this sector:

"On the most basic level, it (military) amounts to equipping the national armed forces with weapon systems and military equipment enabling them to achieve tactical, operational, and strategic military objectives assigned to them in both peace and wartime". (Wisniewski, 2015).

Refers to Figure 1 of Turkish Military-Industrial Complex, the military sector consists of the Turkish Naval Research Command Center (TNRCC) and the Turkish Armed Force (TSK). The TNRCC plays a double role in the military and research sectors, while the TSK becomes the spearhead of recognizing the necessity in the Turkish military. Involving both TNRCC and TSK in the military-industrial complex helps to acknowledge the priority and urgency of what needs to be developed in the very first place for the Turkish defense industry.

\section{Turkish Naval Research Command Center (TNRCC)}

The vision of this Turkish Naval Research Command Center is "to provide the development of original systems in accordance with the international standards, including modern and efficient technological solutions, which can carry the Turkish Naval Forces ahead of the era and minimize the dependency on foreign countries (Armerkom, n.d.)." The TNRCC becomes the basis field of expertise in (1) department of combat system which includes software development group, electronic development group, and system engineering group; (2) electronic warfare group presidency; (3) acoustical research group and; (4) modelling and simulation group (Armerkom, n.d.). Similar to TUBITAK, TNRCC works on the highly substantial naval research and development requiring direct supervision from the navy.

\section{Turkish Armed Force (TSK)}

According to the Article 35 of Turkish Armed Force Internal Service Code 211, the mission of the Armed Forces is to "(1) defend Turkish territory against the foreign-born threats and dangers; (2) ensure that the military strength is maintained and strengthened to ensure deterrence; (3) carry out the missions abroad assigned by the decision of Grand National Assembly of Turkey, and; (4) assist in ensuring international peace" (TSK, 2018).

The structure of the Turkish Armed Force was developed by the establishment of the Turkish Armed Force Foundation (TSKGV), which was the merge of Land Force Command, Naval Forces Command, and Air Force Command in 1987. According to Law 3388, the objective of the Turkish Armed Force Foundation is "to enhance the warfare capability of Turkish Armed Forces through national defense industry, establish new defense industry areas and procure warfare armament by providing the financial and spiritual support of Citizens" (TSKGV, n.d.). In a nutshell, it is clear that military sector becomes the spearhead of defense industry development who could propose the establishment of new technology in defense industry areas and procurement of warfare armament. 


\section{The Role of Industry in the Military-Industrial Complex}

In the framework of the Turkish Military-Industrial Complex, the role of industry is essential, including the large-scale defense firms and the SMEs that become remarkable until this moment. Wisniewski expresses that the industry's role in the Turkish defense industry is to play with several distinct phases, including the $R \& D$ of new technologies, development of final products, production, and servicing decommissioning of platforms and systems (Wisniewski, 2015). In line with this, the SSM expresses that companies in the defense industry should reach its expected transformation from co-production, main platforms, and local production to mastering basic and advanced technologies (Invest in Turkey, 2018).

\section{Large Scale Defense Firms}

Up to 2017, Turkey has owned several large-scale defense firms, of which three are among the world's top 100 defense companies, namely ASELSAN, TAI, and ROKETSAN. In general, large-scale defense firms are the main contractors and responsible for executing great projects/programs. Taking the example of the Turkish Aerospace Industry (TAI) who became the main contractor (co-producer) of the US's F-16. Marked by its success in the production and development of F-16 final products, TAI has gained a respected reputation and entrusted to begin the co-production of SF-26 and CN-235 (Schofield Publishing, 2017). Therefore, the roles of large-scale defense firms are significant for conducting the execution and production of big projects that also build the reputation of defense industry capability.

\section{Small to Medium Enterprises}

Demir, Caymaz, and Erenel explain that the SMEs might also contribute significantly to the national defense industry. Thus, the defense clusters were established to determine their maximum potential (Demir, Caymaz, \& Erenel, 2016). The SMEs under defense cluster may and, in most cases, became the subcontractors of the big defense company in project work packages. They are essential to provide expert services in specific defense industry areas and are specialized in various products and services where they can produce specific products or equipment in high quality (Demir, Caymaz, \& Erenel, 2016, p.8). Up to the year 2015, the Turkish defense cluster has constituted OSSA, HUKD, Eskisehir Aerospace, TSSP, SAHA, and Bursa Aviation (Aktaş, 2016)

\section{Defense and Aerospace Industry Manufacturer Association (SaSaD)}

In addition to large industry working on big projects and SMEs working on specific defense industry areas, there is also another government-made organization associating specifically the defense and aerospace industry area, $\mathrm{SaSaD}$. It was established in 1990 with suggestions and supports from the Ministry of National Defense ( $\mathrm{SaSaD}, 2017) . \mathrm{SaSaD}$ 's original name was the Defense Industry Manufacturer Association, but in 2012 the joint of manufacturers in civil aviation and space changed the name into Defense Industry and Aerospace Industry Manufacturer Association ( $\mathrm{SaSaD}, 2017)$. In general, the role of this organization is to provide cooperation of the members in the demands and supply authorities as well as fully meet the defense and security needs of the state.

The segregation of large industry, SMEs, and SaSad in the industry sector of the military-industrial complex could accommodate and utilize various industries and even maximize the potential of SMEs to work on specific defense industry areas and give enough supply to the demand of national defense products/projects. In general, the design of the Turkish Military-Industrial Complex with a holistic involvement of government, research, military, and the industry sectors with each specific role mentioned above, might be prospectus to the development and independency of the national defense industry if managed consistently.

\section{THE SYNERGY OF TURKISH MILITARY-INDUSTRIAL COMPLEX FROM 2011}

During this period, the Turkish defense industry came up with remarkable achievements by its capability of locally producing the Milgem Class Corvette, ALTAY 
tank, ATAK, ANKA, and the TF-X. This section describes how the synergy among stakeholders in the Turkish Military-Industrial Complex is built.

\section{MILGEM Project}

In 2008, the project launched the first Milgem TCG-Heybeliada, followed by TCG-Buyukada in 2011, TCG-Burgazada in 2016, and TCG-Kinaliada in 2017 (Turkish Navy, n.d.). The Mili-Gemi (Milgem), Turkish's first corvette program, is envisioned to "build a modern littoral combat warship with indigenous capabilities and extensively using the principles of stealth technology in its design" (Global Security, 2018). This project aims to fulfill the needs of the Turkish Naval Forces Command for reconnaissance, surveillance, target identification, early warning, anti-submarine warfare, surface-to-surface and surface-to-air warfare and amphibious operations (Naval Technology, n.d.). The warship operation is projected to cover the Aegean Sea and Eastern Mediterranean (Naval Technology, n.d.) that has become a strategic yet challenging environment for Turkey.

The role of government (SSM) becomes essential to determine which defense firms responsible for developing the project and setting the performance target and other benchmarks, whereas the STM was chosen to be the main contractor of this project. The SSM also determines industrial participation involving and benefiting 50 SMEs of the Turkish defense industry (SSB, 2017). The STM has a role in providing design service, integration of the primary propulsion systems, acquisition of systems, materials and equipment, and integrated logistics service (STM, 2018). To accomplish this, the STM works together with the 50 chosen defense industries, where all the design proposals and progress will always be reported back to the government (SSM).

According to the report of Defense Turkey, the Milgem project promises a more reliable future to the Turkish Defense Industry by supporting their research, design, and production activities (Defence Turkey, 2008). Tubitak MAM contributes by making the indigenous Milgem National Sonar Wet End Parts Production and Integration (Tübitak MAM, n.d.), while TNRCC builds the integration of the locally developed warfare system;
GENESIS to the ship (Turkish Defense Alliance, n.d.). The Turkish Naval Forces initiated the MILGEM project from their necessity of having an indigenous high technology warship. As a response, the government sector appointed defense industries to work on the project and research institutions to be responsible for conducting the needed research and development.

\section{ALTAY Project}

Initially, the objective of this project is "to design, develop, and produce a prototype of a tank domestically, that is equipped with cutting-edge technology weapon systems and other sophisticated technology through the technology transfer" (SSB, 2017). In accomplishing the project, there is the involvement of the Turkish Military-Industrial Complex. The Turkish Land Force (KKK), further explained that the creation of Altay was intended to ensure long-term platform requirements in the future by considering "its capability of high movement and survivability which has long-range and effective firepower into the inventory or removal of other tanks that are coming to the end of their economic and physical lives" (KKK, 2017). According to them, tanks are the backbone of the Commander's indispensable striking power as they provide continuous operational ability with firepower, mobility, armor protection, and strike effect in any battle (KKK, 2017).

Initially, the studies on the current tank project have started in 1996 yet stopped in 2004 due to the project cost. The project then continued in 2005 under the name of the Turkish National Main Battle Tank (ALTAY) project (Defense Aerospace, 2008). The government conducted a feasibility study in determining the production pattern for the ALTAY project and appointed Otokar in 2007 to become the main contractor of the project (Defense Industry Daily, 2018). In 2008, the Turkish government signed a deal with the Republic of Korean government for a $\$ 400$ million MOU in System Design and Development, making the ALTAY project a reality. For the research activity, Otokar as the main contractor has its $R \& D$ unit at Otokar facilities in Sakarya (Army Recognition, 2018), supported with research conducted by the sub-contractors. 
Moreover, there are also numerous subcontractors and foreign cooperation to accomplish this project. As a result of the government's MOU in this project, Otokar received foreign assistance from Hyundai Rotem. For the domestic assistance, this project involved other defense companies in being the sub-contractors such as ASELSAN for fire control systems, MTU Friedrichshafen for the engine, STM for C3I co-development with ASELSAN, MKEK for $120 \mathrm{~mm} / 55$ caliber main gun, and ROKETSAN for Modular Armor Packages (Defense Industry Daily, 2018).

ALTAY project becomes an example of the government's great concern for the success of this project as other than utilizing its domestic defense industry, and the Turkish government has sought foreign aid in accomplishing this project. Otokar was chosen as the main contractor as it has its research and development agency, yet more subcontractors are also hired to work on this project. The success of this project is critical for the Turkish Land Force (KKK) to become one of the fundamental and deterrent assets.

\section{ATAK Project}

ATAK is another modernization project of the Turkish Land Force (KKK). According to the official SSM website, the objective of this project is "to produce and bring into service the reconnaissance and tactical attack helicopter required by the Land Force Command" (SSB, 2017). The development and modernization of ATAK project will become necessary for the Land Command to meet its requirement of "a high-performance attack helicopter, capable of functioning at high altitude, day/night and in poor weather conditions as the TLF's attack and reconnaissance platform will be satisfied" (KKK, 2017). Through this program, the Turkish Land Force is expected to deliver a total of 91 units where nine of them will be delivered to the Ministry of Interior, and the rest will be used for the operation of the force (TAI, 2017).

The government assigned the Turkish Aerospace Industry (TAI) to be responsible for conducting the construction of the project. The build-up of this helicopter 'T129' comes from a joint design and manufacture with the Italian-based AgustaWestland
'A129' Mangusta (TAI, 2017). TAI developed the A129 framework into 'a more indigenous' locally produced helicopter by adopting local technologies. Since September 2007, a joint venture agreement was signed between the TUBITAK, Meteksan Defense, and Bilkent University to build modern millimeter-wave radar for the T129 (TAI, 2017). This kind of additional technology stipulates the value of ATAK helicopters as a Turkish national helicopter regardless of the origin of the platform.

In accomplishing the project, $\mathrm{TAI}$, as the main contractor, has built partnerships with other companies both local and foreign, to become the sub-contractors and sub-parts production such as ASELSAN for the electronic warfare, ROKETSAN for the missile equipment and Honeywell International and Rolls-Royce for the engine (Navuluri, 2015). ATAK project becomes another example of the Turkish defense project, where the initiation came from the military sector. The government assigned a large-scale industry as the main contractor of the project and determined the type of products. TAI, which has its research and development unit, allowed to work together with foreign defense industry companies to achieve project success.

\section{ANKA Project}

The initiation of this project is more to the historical reasons that the Turkish Land Force had to experience after the end Cold War and close to the end of the 1990s. At a very glance, this project aims "to develop a national UAV System to meet the requirements of the Turkish Armed Forces for reconnaissance, surveillance, target, recognition, and detection (SSB, 2017)". According to the Turkish Land Force, a 'New Force Structure' was required to be established after many vulnerabilities happened, including the Warsaw Pact's collapse, the disintegration of the Soviet Union, and the vulnerabilities of the Turkish Land Force itself (KKK, 2017). In this 'New Force Structure,' there are ten characteristics; where some of them are "(1) adaptable to a future combat environment, with; (2) high mobility and firepower, and; (3) capability to detect and identify the enemy from a distance" (KKK, 2017). To meet the 
characteristic, UAV battalions were established and added to the organization of Army Commands in 2007 to improve reconnaissance, surveillance, and target acquisition capabilities (KKK, 2017).

The role of government is determining which company passed the 'Acceptance Trials and Requirements'. In 2013, TAI passed the 'Acceptance Trials' of ANKA MALE UAV (Airforce Technology, n.d.), while in October in the same year, a specific contract for initial production of ten ANKA systems was then negotiated and signed under the name of ANKA-S project (TAI, 2017). From the 2011 to 2017 period, there was no information on what institutions TAI had cooperated with to conduct R\&D activities, yet before the SSM TAI was accepted, the project had conducted $R \& D$ activities at its facilities. Since 2003, TAI has built cooperation with the Middle East Technical University (METU) Technology Development Zone-Teknokent for conducting the "R\&D" and "Software" activities (TAI, 2017). TUSAS R\&D buildings (TUSAS-Teknokent) are located in METU Teknokent Defense Industry Research and Technology Development Sub-region, which has been operating since 2004 and hiring about 250 people in both buildings (TAI, 2017).

In the development of this project, TAI conducted the design and prototype production by themselves. However, after TAI passed the acceptance trials and approved by the SSM, it started to cooperate with other domestic defense companies to equip and supply the UAV with additional technologies and payloads. Some of those domestic defense companies are ASELSAN for the radar systems, ROKETSAN for the missiles and missile launcher, and TUSAS Engine Industry for the turbo propeller engine. Up to this point, it can be argued that the ANKA project becomes another example of a project where the initiation comes from the military sector.

\section{TF-X Project}

It has become a necessity for the Turkish Air Force to have its indigenous 5 th generation stealth fighter aircraft starting in 2030. The Turkish Air Force currently maintains a total of 262 stealth fighter aircraft with a configuration consisting of 196 F-16C Fighting Falcon and 44 F-16D Fighting Falcon produced in 1987 (THKK, n.d.). As those fighter jets have come into age, the needs of new-generation aircraft for the Turkish Air Force are considered by the government. Following Decision no. 545 adopted at the DIEC on December 15, 2010, those large number of F-16C and F-16D will be removed gradually starting from 2030 and the 'in-progress' development of TF-X are planned to replace the fleet (Sünnetçi, 2018).

Initially, the first contract of this project was signed on August 23, 2011 between the SSM and TAI for the Concept Development and Preliminary Design phase, which was accepted by the SSM in early 2014 (Sünnetçi, 2018). The SSM further issued a Request for Information (RFI) on March 13, 2015, to the international companies capable of "design, develop and/or produce the 5th generation aircraft under the Engineering Development \& Preliminary Design Phase" (Sünnetçi, 2018). Shortly, based on the evaluation of the proposals, BAE Systems came to the forefront of other candidates as the Foreign Cooperation Company (FCC). The SSM put BAE Systems into a pre-contract study with TAI that valued at $£ 100$ million on January 28, 2017, to build collaboration under the Engineering Development \& Preliminary Design Phase of the TF-X Program (BAE Systems, 2017).

In the Concept Development and Preliminary Design phase, TAI sought assistance from the SAAB Aircraft Company as the Technical Support and Assistance Provider (TSAP) and produced three conceptual designs of TF-X; namely FX-1, FX-5, and FX-6 by distinguishing the configuration of the engine, wing design and back tail (Sünnetçi, 2018). As the government put BAE Systems into a pre-contract study with TAI, they conducted research together along with Airbus Defense System and SAAB Aircraft Company before BAE Systems officially became the Foreign Cooperation Company. Under the joint venture, both companies still look for support from other defense companies to complete the sub-parts and/or become the sub-contractors of the project. In this project, TAI cooperated with ASELSAN to develop and equip some technologies like Active Electronically Scanned Array (AESA), Electronic Warfare System, Digital Cockpit, Integrated Modular Avionics Mission 
Computer and Infrared Search and Track (IRST) System for the TF-X (Sünnetçi, 2018). In 2017, the British Rolls-Royce and Kale group came under joint venture cooperation called TAEC to develop a new engine of TF-X, in which all the patents of this engine will fully belong to Turkey.

\section{Problems and Challenges}

There will always be challenges in any effort of development, including the development of the Turkish defense industry. The problems and challenges here at least come from the sectors of political, economic, and industry internal. According to one of the company executives involved in Turkish arms export activities, "Turkey's local industry faces many challenges from technology to competitiveness, on the other hand, Turkish companies have competitive advantages in engineering quality and low labor costs." (Bekdil, 2017).

In 2016, Turkey had to deal with the refugee crisis and the civil war with Syria, while the situation was getting worse with the civilians' coup attempt and Erdogan's arresting policy. This political turmoil hit Turkey by losing $68 \%$ of its FDI from $\$ 7.5$ billion in 2015 to $\$ 2.5$ in 2016 with the same period (MacBride, 2016). The Turkish lira was also facing depreciation and signified the activities in the defense industry sector. In January 2011, US $\$ 1$ was still valued at 1.5-1.6, but the value increased to 3 in January 2016 and 3.8 in January 2017 (Tradingview, 2018). It signified the cost of local defense industry development, including the cost for research and development and imported components of those locally made products.

For the internal industry challenges, Mevlutoglu mentioned that the problems are the effectiveness and quantity of human resources, the lack of focus and vertical expertise. He pointed out that the heavy focus on import substitution had a negative effect on the competitive power of the sector while compared to the amount of development and production projects, the number of employees was critically low (Mevlutoglu, 2017). He added that the high number of projects and programs are not ideally made, resulting in a lack of focus and deficiency for developing expertise (Mevlutoglu, 2017).

\section{THE BENEFITS FROM TURKISH DEFENSE INDUSTRY DEVELOPMENT}

Turkey's concern about the development and independency of its domestic defense industry has brought significant impacts to the state, especially in the political and military sectors.

\section{Political Sector}

By the development and modernization of the defense industry, Turkey has strengthened its political position through defense industry ties with some countries and by becoming the fourth state in the world capable of producing the fifth-generation fighter jet (TF-X project) after US, China and Russia (Daily Sabah, 2018). For accomplishing the TF-X project, Turkey initiated a joint venture with Britain's company BAE System in January 2017 , with a collaboration costs of $£ 100$ million (known as the Head of Agreement). The signatories of this agreement were Turkey's President Recep Tayyip Erdogan and United Kingdom's Prime Minister Theresa May.

Another example is the Milgem project that has strengthened the political ties of Turkey and Pakistan. In 2016, Pakistan Navy signed a contract to acquire four Milgem class ships to replace Navy's old Tariq class ships (Shay, 2018). During the ceremony of TCG Burgazada in 2016, Erdogan expressed that Turkey will meet the ambition of eliminating foreign dependency in the defense industry by 2023 (Presidency of the Republic of Turkey, 2016). Previously, during the introduction of the first self-produced Milgem in 2011, Erdogan expressed that Turkey has currently taken its place among ten countries that could design and conduct warships (Y-Net News Agencies, 2011). By their agreement to strengthen defense industry ties in May 2016, the relations between Turkey and Pakistan have reached beyond diplomatic interaction between two states (Shay, 2018).

Other than those two projects, the following tables 3 and 4 present states politically becoming trade partners in the defense industry sector. The cooperation data between Turkey and the six biggest export destination countries for Turkish arms transfers presented in this table was retrieved from SIPRI (SIPRI, 2018). However, not all the actual agreements of arms transfers are presented. Table 3 
shows more on the turnover or the exact value of cooperation in million dollars, while table 4 shows more the type of defense armament traded. From these data, it can be seen that politically, Turkmenistan and UAE are the biggest trade partner for the Turkish defense industry, while in South East Asia, Malaysia becomes the biggest one through the procurement of APC and IFV. Please be note that the contract information or the information on the value of agreement in table 4 can be different from the exact value of turnover in table 3 .

Table 3. Turkish Top 6 Arms Export Destination Countries (in million US\$)

\begin{tabular}{ccccccccc}
\hline Country & 2011 & 2012 & 2013 & 2014 & 2015 & 2016 & 2017 & Total \\
\hline Turkmenistan & 20 & 20 & 40 & 40 & 91 & 123 & 62 & 396 \\
UAE & & 10 & 20 & 20 & 80 & 80 & 80 & 290 \\
Saudi Arabia & 33 & 33 & 44 & 39 & 52 & 39 & 13 & 252 \\
Pakistan & 22 & 22 & 22 & & 24 & & 8 & 98 \\
Malaysia & & & & 14 & 14 & 24 & 36 & 88 \\
Azerbaijan & 7 & 20 & 5 & 17 & 9 & 16 & & 74 \\
\hline
\end{tabular}

Data is adapted from SIPRI Online Database 2018. Retrieved from http://armstrade.sipri.org

\section{Military Sector}

The development and modernization of the Turkish defense industry have brought a positive impact to the Turkish Armed Force as it aims to fulfils the needs of the force. Taking the Turkish Land Force as an example, they sought "to modernize many military armaments from small military equipment and artillery until the armored vehicles, helicopters, and UAV as those needed to be used in the force operational task" (KKK, 2017). Similar to the Turkish Air Force, they considered the age of the existing fighter jet F-16C and F-16D jets, made in 1987 (THKK), and sought to replace with their indigenous 5th generation fighter jet in 2030.

In general, during the 2011-2017 period, the global market demand of the Turkish defense industry was more to the needs of the armored vehicle, ships, missiles, and artillery. It was followed by the demand for aircraft and sensors, ranked fifth and sixth. Putting the defense industry independency in the first place, the modernization and development of the Turkish defense industry have increased the capability of the state to protect its region. Consequently, President Recep Tayyip Erdogan became very confident that the Turkish Navy has increased its military power in the Eastern Mediterranean and the Aegean Sea region by utilizing its indigenous Milgem ship in 2016:

"The recent incidents in the Eastern Mediterranean and the Aegean have once again shown that our Naval Forces should be just as strong as other units of ours...Those who assumed they could engage in activities in the Eastern Mediterranean and the Aegean at the coast of Turkey have now started to understand how wrong they were. We will not allow bandits at sea, just as we have punished terrorists in Syria." (Presidency of the Republic of Turkey, 2018) 
Table 4. The Registered Trade of Turkish Arms Export

\begin{tabular}{|c|c|c|c|c|c|}
\hline Recipient & Product & Category & Order & $\begin{array}{l}\text { Year of } \\
\text { Order }\end{array}$ & Information \\
\hline \multirow[t]{5}{*}{ Turkmenistan } & YTBK & Patrol craft & 2 & 2011 & - \\
\hline & YTBK & Patrol craft & 8 & 2012 & - \\
\hline & Dearsan $33 \mathrm{~m}$ & FAC & 6 & 2014 & - \\
\hline & Cobra & APV & 34 & 2015 & - \\
\hline & Navigator & APC & 28 & 2015 & - \\
\hline \multirow[t]{3}{*}{ UEA } & Canavr & Towed MRL & 8 & 2012 & - \\
\hline & CIRIT & ASM & 10,000 & 2013 & Under the $\$ 196 \mathrm{~m}$ deal \\
\hline & ARMA & APC & 400 & 2017 & Assembled in UAE \\
\hline \multirow[t]{6}{*}{ Saudi Arabia } & M-113A300 & APC & 312 & 2010 & Under the $\$ 324 \mathrm{~m}$ deal \\
\hline & M-113A300 & $\mathrm{APC}$ & 320 & 2011 & Under the $\$ 200 \mathrm{~m}$ deal \\
\hline & M-113A300 & APC & 350 & 2013 & Under the $\$ 360 \mathrm{~m}$ deal \\
\hline & Panter $155 \mathrm{~mm}$ & Towed gun & 60 & 2009 & - \\
\hline & STM-158m & Oiler & 1 & 2013 & Under the $\$ 80 \mathrm{~m}$ deal \\
\hline & MilGem & Frigate & 4 & 2017 & $\begin{array}{l}2 \text { might be built-in } \\
\text { Pakistan }\end{array}$ \\
\hline \multirow[t]{4}{*}{ Pakistan } & $\mathrm{T}-37 \mathrm{~B}$ & Trainer aircraft & 34 & 2015 & Second-hand; aid \\
\hline & ASELPOD & $\begin{array}{l}\text { Aircraft EO } \\
\text { system }\end{array}$ & 8 & 2016 & $\begin{array}{l}\text { Under the } \$ 25 \mathrm{~m} \text { deal; } \\
\text { for JF-17 combat }\end{array}$ \\
\hline & ASELPOD & $\begin{array}{l}\text { Aircraft EO } \\
\text { system }\end{array}$ & 17 & 2017 & $\begin{array}{l}\text { Under the } \$ 25 \mathrm{~m} \text { deal; } \\
\text { for JF-17 combat }\end{array}$ \\
\hline & Pars & $\mathrm{APC}$ & - & 2011 & $\begin{array}{c}\text { Part of } \$ 2.5 b \\
\text { deal; delivery in } 2016-19\end{array}$ \\
\hline \multirow[t]{4}{*}{ Malaysia } & Pars IFV-25 & IFV & 46 & 2011 & $\begin{array}{l}\text { Part of } \$ 2.5 \mathrm{~b} \text { deal, } \\
\text { delivered 2014-18 }\end{array}$ \\
\hline & Pars IFV-30 & IFV89 & 122 & 2011 & $\begin{array}{c}\text { Part of } \$ 2.5 b \text { deal, } \\
\text { delivered } 2017-19\end{array}$ \\
\hline & Cobra & APV & 35 & 2010 & $\begin{array}{c}\text { Under the } \$ 21 \mathrm{~m} / \$ 30 \mathrm{~m} \\
\text { deal }\end{array}$ \\
\hline & Shorland & APV & 37 & 2010 & $\begin{array}{c}\text { Under the } \$ 21 \mathrm{~m} / \$ 30 \mathrm{~m} \\
\text { deal }\end{array}$ \\
\hline \multirow[t]{3}{*}{ Azerbaijan } & T-107 & $\begin{array}{c}\text { Self } \\
\text { propelled } \\
\text { MLR }\end{array}$ & 30 & 2010 & $\begin{array}{c}\text { Under the } \$ 244 \text { million } \\
\text { deal }\end{array}$ \\
\hline & $\mathrm{T}-122$ & $\begin{array}{c}\text { Self } \\
\text { propelled } \\
\text { MLR }\end{array}$ & 40 & 2015 & $\begin{array}{c}\text { Under the } \$ 244 \text { million } \\
\text { deal }\end{array}$ \\
\hline & $\mathrm{T}-300$ & $\begin{array}{l}\text { Self-propelled } \\
\text { MLR }\end{array}$ & 20 & 2015 & $\begin{array}{c}\text { Under the } \$ 244 \text { million } \\
\text { deal }\end{array}$ \\
\hline
\end{tabular}

Data is adapted from SIPRI Online Database 2018. Retrieved from: http://armstrade.sipri.org 


\section{CONCLUSION}

By 2017, the Turkish defense industry has developed into the level of the local production stage, which can be seen through its capability to build indigenous defense products. Those five examples of the Turkish defense project depict how the military sector plays a vital role in initiating the development of the national defense project. Following the military initiatives, Turkey's government responded by considering the proposed project, conducted an evaluation, and further determined the most suitable industry for the project as the main and subcontractors. In executing the project, industries work together with the research sector (including university) for research and development activities. Hence, the synergy among the Turkish Military-Industrial Complex involves stakeholders in a more precise pattern from the military to the research sector to ensure the success of the project.

By understanding the role of each stakeholder and the synergy among them in the Turkish Military Industrial Complex, Erdogan's goal of defense industry independency in 2023 might be achievable if the synergy among military, government, research, and industry sectors are maintained and enhanced. So far, the synergy has led to the fast growth of Turkish defense industry capability and independency, further benefiting the political and military sectors of the state. However, problems that might challenge Turkey in this period, such as the external factors and industry internal, must also be considered. Therefore, the Turkish Military-Industrial Complex can become a holistic lesson on how developing countries develop their defense industries.

\section{REFERENCE}

Airforce Technology. (n.d.). Anka MALE Unmanned Aerial Vehicle (UAV). Retrieved November 19, 2018, from https://www.air force-technology.com/projects/anka-male-un manned-aerial-vehicle-uav-turkey/

Aktaş, B. (2016). Overview of Turkish Defence and Aerospace Industry (Official Presentation of the Industrialization Department Head SSM, Ministry of National Defence, Turkey). Retrieved November 26, 2018, from BCl Aerospace: http://seattle.bciaerospace.com

Armerkom. (2018, November 28). About Armerkom. Retrieved from Armerkom: http://www.armerk.tsk.tr/eng/index.html
Armerkom. (2018, November 28). Organization. Retrieved from Armerkom: http://www.armerk.tsk.tr/?organizasyon.html Armerkom. (2018, November 28). Our Vision. Retrieved from Armerkom: http://www.armerk.tsk.tr/?vizyon.html

Army Recognition. (2018, November 27). Altay MBT (Main Battle Tank). Retrieved 2 2018, December, from https://www.ar myrecognition.com/turkey_turkish_heavy_ar moured_tanks_uk/altay_turkish_main_battle_tank_vehi cle_technical_data_sheet_specifications_description_pic

Army Recognition. (2018, May 20). Contract for Mass Production of Turkish Altay Tank MBT will be Inked Soon. Retrieved December 2, 2018, from https://www.armyrecogni tion.com/may_2018_global_defense_securi ty_army_news_industry/contract_for_mass_produc tion_of_turki

BAE Systems. (2017, January 28). BAE Systems signs Heads of Agreement for a future contract with Turkish Aerospace Industries for TF-X Programme. Retrieved December 3, 2018, from https://www.baesystems.com/en-uk/arti cle/bae-systems-signs-heads-of-agreement-for-a-future-con tract-with-turkish-aerospace-industries-for-tf-x--programme

Bekdil, B. E. (2017, January 19). Turkey Launches 'Aggressive' Defense Export Campaign. Retrieved from Defense News: https://www.defensenews.com/global/2017/01/19/tur key-launches-aggressive-defense-export-campaign/

Daily Sabah. (2018, April 27). Defense Giants to Develop Systems of National Fighter Jet. Retrieved December 4, 2018, from https://www.dailysabah.com/defense/2018/04/27/de fense-giants-to-develop-systems-of-national-fighter-jet

Daily Sabah. (2018, January 31). Turkey's defense projects reach 600 , hit $\$ 60 B$. Retrieved November 20, 2018, from https://www.dailysabah.com/defense/2018/01/31/tur keys-defense-projects-reach-600-hit-60b

Defence Turkey. (2008). Istanbul Naval Shipyard: A Major Player in Turkish Naval Projects. Retrieved November 28, 2018, from Defence Turkey: http://www.defenceturkey.com/en/con tent/istanbul-naval-shipyard-a-major-player-in-turkish-na val-projec

Defense Aerospace. (2008, September 12). Turkey's National Main Battle Tank Project (ALTAY) Started with the Ceremony Held at OTOKAR Factory. Retrieved November 19, 2018, from http://www.defense-aerospace.com/articles-view/re lease/3/97840/turkey\%E2\%80\%99s

Defense Industry Daily. (2018, November 13). Turkey \& South Korea's Altay Tank Project. Retrieved December 2, 2018, from https://www. defenseindustrydaily.com/tur key-signs-deal-with-s-korea-for-altay-tank-project-05012/

Demir, K. A., Caymaz, E., \& Erenel, F. (2016, June 25). Defense Industry Clusters in Turkey. Retrieved October 1, 2018, from Research Gate: https://www.researchgate.net/publica tion/304425124_Defense_Industry_Clusters_in_Turkey

Given, L. M. (2008). Explanatory Research. The SAGE Encyclopedia of Qualitative Research Methods. Retrieved January 3, 2019, from http://methods.sagepub.com/reference/sage-en cyc-qualitative-research-methods/n164.xml

Global Security. (2018, April 3). TCG Heybeliada - (MILGEM - Milli Gemi - National Ship). Retrieved from https://www.glo balsecurity.org/military/world/europe/tcg-milgem.htm Global Security. (2018, April 3). Turkey Domestic Arms Industry. 
Retrieved September 25, 2018, from https://www.globalse curity.org/military/world/europe/tu-industry.htm

Invest in Turkey. (2018, January). Turkish Defense \& Aerospace Industry Official Presentation. Retrieved November 19, 2018, from Invest in Turkey: http://www.invest.gov .tr/en-US/infocenter/publications/Documents/DEFENSE-AER OSPACE.INDUSTRY.pdf

KKK. (2017, December 2). Armored Units. Retrieved October 30, 2018, from http://www.kkk.tsk.tr/en/Siniflar/ZirhliBirlikler.as px

KKK. (2017, October 30). Turkish Land Force Modernization Projects. Retrieved December 2, 2018, from http://ww w.kkk.tsk.tr/en/Modernizasyon/Modernizasyon.aspx

KKK. (2017, October 30). Turkish Land Forces History. Retrieved 2018, from http://www.kkk.tsk.tr/en/KKKHakkinda/KKKtari hce.aspx

MacBride, E. (2016, December 13). At a Tipping Point: A Currency Crisis Roils Turkey's Economy. Retrieved November 21, 2018, from https://www.cnbc.com/2016/12/13/at-a-tip ping-point-a-currency-crisis-roils-turkeys-economy.html

Mevlutoglu, A. (2017). Commentary on Assessing the Turkish Defense Industry: Structural Issues and Major Challenges. Defense Studies, 17(3).

Naval Technology. (2018, October 9). Milgem Class Multimission Corvettes. Retrieved from https://www.naval-technology .com/projects/milgem class corvett/

Navuluri, B. (2015, December 14). Rolls-Royce-Honeywell Joint-Venture to Supply Engines to Turkey's New Helicopter. Retrieved December 2, 2018, from https://www.air force-technology.com/uncategorised/newsrolls-royce-honey well-jv-to-supply-engines-to-turkey

Ongur \& Partners International Law Firm. (2018, October 9). Legislations: Law No. 3238. Retrieved from http://ww w.ongurpartners.com/legistlation/48-law-no-3238.html

Presidency of the Republic of Turkey. (2016, June 18). Turkey is advancing with determination on the path to becoming self-sufficient in defense industry. Retrieved December 4, 2018, from https://www.tccb.gov

.tr/en/news/542/44445/turkey-is-advancing-with-determina tion-on-the-path-to-becoming-self-sufficient-in-defense-in dustry

Presidency of the Republic of Turkey. (2018, November 4). We will never allow initiatives that are aimed at usurping the natural resources in the Eastern Mediterranean. Retrieved December 4, 2018, from https://www.tccb.gov .tr/en/news/542/99532/-we-will-never-allow-initia tives-that-are-aimed-at-usurping-the-natural-resourc es-in-the-eastern-mediterranean-

SAGE Tubitak. (2013). Products/Projects. Retrieved November 26 2018, from SAGE Tubitak: http://www.sage.tubitak.gov .tr/en

SAGE Tubitak. (n.d.). (n.d.). About us. Retrieved October 1, 2018, from SAGE Tubitak: http://www.sage.tubitak.gov.tr/en/ku rumsal/about-us

SaSaD. (2012). Defense and Aviation Industry Performance Report. Ankara: Defense and Aerospace Industry Manufacturers Association.

SaSaD. (2014). Defense and Aviation Industry Performance Report. Ankara: Defence and Aerospace Industry Manufacturers
Association.

SaSaD. (2015). Defense and Aviation Industry Performance Report. Ankara: Defense and Aviation Industry Manufacturers Association.

SaSaD. (2016). Defense and Aviation Industry Performance Report. Ankara: Defense and Aerospace Industry Manufacturers Association.

SaSaD. (2017). About Us. Retrieved November 30, 2018, from SaSaD: http://www.sasad.org.tr/en/about-us

Schofield Publishing. (2017, September 12). Turkish Aerospace Industry. Retrieved November 13, 2018, from http://www.manufacturing-today-eu rope.com/2017/09/12/turkish-aerospace-industries/

Seren, M. (n.d.). Defense Industry: From Ottoman Period to Today. Retrieved November 8, 2018, from http://m5der gi.com/en/2018/05/defense-industry-from-ottoman-peri od-to-today/

Sezer, J. H. (2015, May 27). Erdogan Aims to Turn Turkey into Major Defense Industry Power. Retrieved from Reuters: https://www.reuters.com/article/us-turkey-election-de fence/erdogan-aims-to-turn-turkey-into-major-defense-in dustry-power-idUSKBNOOCOFT20150

Shay, S. (2018, August 8). Pakistan Acquires Four MILGEM-Class Ships from Turkey. Retrieved December 4, 2018, from https://www.israeldefense.co.il/en/node/34912

SIPRI. (2018, March 12). TIV of Arms Exports from the Top 50 Largest Exporters 2011-2017. Retrieved December 12, 2018, from SIPRI Online Database: http://armstrade.sip ri.org/armstrade/page/toplist.php

SIPRI. (2018, March 12). Transfers of Major Weapons: Deals with Deliveries or Orders Made for 2011 to 2017. Retrieved December 12, 2018, from SIPRI Online Database: http://armstrade.sipri.org/armstrade/page/trade_register.php

SSB. (2017). About the Project: Altay Main Battle Tank̄. Retrieved December 2, 2018, from https://www.ssb.gov.tr/WebSite/ contentlist.aspx? PagelD $=366 \&$ Lang $\mid \mathrm{D}=2$

SSB. (2017). About the Project: ANKA Unmanned Aerial Vehicle. Retrieved December 2, 2018, from https://www.ssb.gov .tr/WebSite/contentlist.aspx?PagelD =364\&LangID $=2$

SSB. (2017). About the Project: ATAK Reconnaissance and Tactical Attack Helicopter. Retrieved December 2, 2018, from https://www.ssb.gov.tr/WebSite/contentlist.aspx?Page $\mathrm{ID}=363$ \&Lang $\mid \mathrm{D}=2$

SSB. (2017). About the Project: Milgem National Ship. Retrieved November 19, 2018, from https://www.ssb.gov.tr/Website/ contentList.aspx?PagelD $=371$ \&Lang ID $=2$

SSB. (2017). About Us. Retrieved October 9, 2018, from https://w ww.ssb.gov.tr/WebSite/contentlist.aspx?Page $\mid \mathrm{D}=39$ \&Lang $\mid \mathrm{D}=2$

SSB. (2017). Our Defence Industry. Retrieved September 27, 2018, from https://www.ssb.gov.tr/WebSite/contentlist.aspx?Page $\mathrm{ID}=47$ \& Lang $\mid \mathrm{D}=2$

SSB. (2017). Research Development Program for Defense Industry (SAYP). Retrieved November 28, 2018, from SSB: https://w ww.ssb.gov.tr/WebSite/contentlist.aspx?Page $\mid \mathrm{D}=86$ \& Lang $\mid \mathrm{D}=1$

STM. (2018). Milgem. Retrieved December 2, 2018, from https://www.stm.com.tr/en/products/milgem

Sünnetçi, I. (2018). A Closer Look at the Turkish Defence Industry's 
Fixed Wing Air Platforms Sector. Retrieved December 3, 2018, from Defence Turkey: https://www.defencetur key.com/en/content/a-closer-look-at-the-turkish-defence-in dustr

TAI. (2017). National Combat Aircraft. Retrieved December 3,

2018, from https://www.tai.com.tr/urun/milli-muharip-ucak

TAI. (2017). Our Facilities. Retrieved December 2, 2018 2, 2018, from https://www.tai.com.tr/kurumsal/tesislerimiz

TAI. (2017). Phoenix: MALE UAV System. Retrieved December 2, 2018, from https://www.tai.com.tr/urun/anka

TAI. (2017). T129 ATAK. Retrieved December 2, 2018, from from https://www.tai.com.tr/urun/t129-atak

THKK. (n.d.). Aircraft in Inventory. Retrieved December 3, 2018, from https://www.hvkk.tsk.tr/en-us/Turkish_Air_Force/To days_Air_Force/Aircraft_in_the_Inventory

Tradingview. (2018). USDTRY Forex Chart. Retrieved November 21, 2018, from https://www.tradingview.com/symbols/US DTRY/?utm_campaign $=$ chart\&utm_medium $=$ widget\&utm source $=$ tradingeconomics. com\&utm term $=F$ FX3AUSDTRY

TSK. (2018, November 28). Mission. Retrieved from https://ww w.tsk.tr/Sayfalar?viewName=Mission

TSKGV. (n.d.). About Us. Retrieved November 28, 2018, from https://www.tskgv.org.tr/contents/kurumsal/616

Tübitak. (2018). R\&D Activities. Retrieved November 26, 2018, from http://www.tubitak.gov.tr/en.

Tübitak MAM. (n.d.). Materials. Retrieved November 30, 2018. Retrieved from Tubitak Marmara Research Center: http://mam.tubitak.gov.tr/sites/images/mam---/me_en.pdf

Turkish Defense Alliance. (n.d.). Success Stories: Milgem. Retrieved November 30, 2018, from http://www.tda.gov.tr/En/Suc cess-Stories/1/MILGEM.

Turkish Navy. (n.d.). ADA Class (Milgem). Retrieved November 30, 2018, from https://turkishnavy.net/ada-class-milgem/

Wisniewski, R. (2015). Military-Industrial Aspects of Turkish Defence Policy. Rocznik Integracji Europejskiej, 215-228.

Y-Net News Agencies. (2011, September 27). Turkey Introduces First Self-Produced Warship. Retrieved November 19, 2018, from https://www.ynetnews.com/arti cles/0,7340,L-4128824,00.html

Zikmund, W. B. (2012). Business Research Methods: with Qualtrics Printed Access Card. Cengage Learning. 